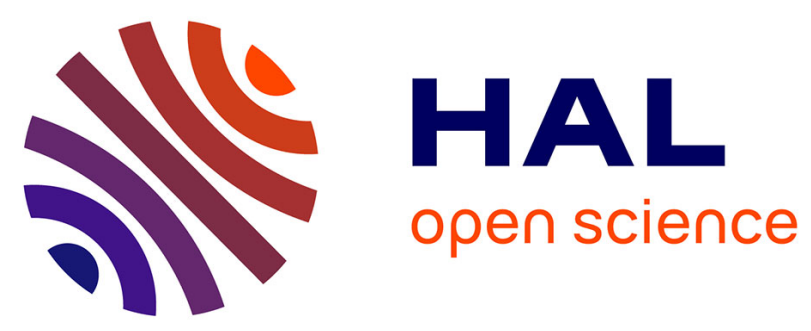

\title{
Long term reference change value of creatinine in HIV-positive patients with anti-retroviral therapy: A new tool in clinical practice
}

Stéfanie Badiou, A. Cournil, Anne-Sophie Bargnoux, S. Toubal, A.M. Dupuy, C. Fernandez, H. Peyriere, J. Reynes, Jean-Paul Cristol

\section{To cite this version:}

Stéfanie Badiou, A. Cournil, Anne-Sophie Bargnoux, S. Toubal, A.M. Dupuy, et al.. Long term reference change value of creatinine in HIV-positive patients with anti-retroviral therapy: A new tool in clinical practice. Clinical Biochemistry, 2015, 48 (9), pp.622-624. 10.1016/j.clinbiochem.2015.01.002 . hal-01767864

\section{HAL Id: hal-01767864 \\ https://hal.umontpellier.fr/hal-01767864}

Submitted on 21 Jul 2018

HAL is a multi-disciplinary open access archive for the deposit and dissemination of scientific research documents, whether they are published or not. The documents may come from teaching and research institutions in France or abroad, or from public or private research centers.
L'archive ouverte pluridisciplinaire HAL, est destinée au dépôt et à la diffusion de documents scientifiques de niveau recherche, publiés ou non, émanant des établissements d'enseignement et de recherche français ou étrangers, des laboratoires publics ou privés. 


\title{
Long term reference change value of creatinine in HIV-positive patients with anti-retroviral therapy: A new tool in clinical practice
}

\author{
S. Badiou ${ }^{\text {a,b }}$, A. Cournil ${ }^{\text {c }}$, S. Toubal ${ }^{\text {a }}$, A.S. Bargnoux ${ }^{\text {a }}$, A.M. Dupuy ${ }^{\text {a }}$, C. Fernandez ${ }^{\text {d }}$, H. Peyriere ${ }^{\text {, }}$, \\ J. Reynes ${ }^{\text {c,d }}$, J.P. Cristol ${ }^{\mathrm{a}, \mathrm{b}, *}$ \\ ${ }^{a}$ Department of Biochemistry, Montpellier University Hospital, Montpellier, France \\ ${ }^{\mathrm{b}}$ UMR 204 NUTRIPASS, Universités Montpellier I/II, Montpellier, France \\ c UMI 233, IRD Inst Res Devt, Université Montpellier I, Montpellier, France \\ ${ }^{\mathrm{d}}$ Department of Infectious Diseases, Montpellier University Hospital, Montpellier, France
}

\section{A B S T R A C T}

Background: The use of reference change value (RCV) instead of reference interval emerged as an alternative approach for longitudinal interpretation of biological marker. Follow-up of creatinine variation in HIV-positive adults remains a challenge in order to prevent renal complications.

Objectives: To determine the long term RCV of creatinine in HIV-positive adults receiving anti-retroviral therapy (ART) according to the use of tenofovir or ritonavir.

Design and methods: Longitudinal study of 24 months that include 124 HIV-positive patients followed in HIV outpatient unit. Plasma creatinine was measured at $0,6,12$ and 24 months in order to calculate the RCV.

Results: In the whole group, a 24-month RCV of creatinine was $22.5 \%$. Whatever the ART, the index of indi-viduality was $<0.6$. Significantly higher RCV of creatinine was observed in patients receiving the association tenofovir and ritonavir (28\%) compared to the patients receiving i) tenofovir without ritonavir (21.9\%), ii) no tenofovir but ritonavir (22.2\%), and iii) no tenofovir and no ritonavir (19.7\%).

Conclusions: The low value of index of individuality pinpointed that RCV should be used to identify critical change in serial creatinine results in HIVpositive adults. RCV of creatinine under ART was around $20 \%$ but reached $28 \%$ in case of association of tenofovir and ritonavir.

Keywords:

Creatinine; HIV; Ritonavir; Reference change value; Renal; tenofovir

\section{Introduction}

Plasma creatinine level is commonly used as a biomarker for renal function assessment. Single level of plasma creatinine is mainly interpreted using reference interval values or integrated in algorithms in order to estimate the glomerular filtration rate (GFR) [1]. Reference interval values for creatinine are variable for age and gender, often provided by manufacturers, but should be re-assessed in each laboratory for each method in healthy volunteers. Nevertheless, serial measures of plasma creatinine level could be interpreted through another approach using the reference change value (RCV) instead of reference interval. The concept of RCV takes into account the analytical and biological variations of a biomarker in order to determine which percent change between two consecutive measurements may be considered as a critical difference [2]. Biological variations depended to intra- and inter-individual variations, assessed through within$(\mathrm{CVi})$ and between-(CVg) subject coefficients of variation, respectively.

\footnotetext{
* Corresponding author at: Department of Biochemistry, Lapeyronie Hospital, F34295 Montpellier, France.

E-mail address: jp-crsitol@chu-montpellier.fr (J.P. Cristol).
}

Determination of RCV for a biomarker in a healthy population is not always transposable to specific clinical conditions [3], as demonstrated recently for renal recipient patients [4]. No data are available today, for RCV of creatinine in HIV-positive patients. The purpose of the present study was to calculate long term RCV of creatinine in HIV-positive adults receiving anti-retroviral therapy (ART).

\section{Patients and methods}

This is a longitudinal study of HIV-positive adults seen at the Montpellier University Hospital HIV outpatient clinic. The study was approved by the local ethic committee and was declared under the number DC-2012-1579. All patients enrolled have serial monitoring at $0,6( \pm 1), 12( \pm 1)$ and $24( \pm 1)$ months in the department of Infectious Diseases, with a standardized biological assessment including creatinine measure with enzymatic method (Diasys reagent, Diasys Diagnostic System, Holzheim, Germany) adapted on AU2700 Olympus analyzer (Beckman, Villepinte, France). Clinical and biological data were included in a computerized medical record (e-NADIS), after patients received oral information and given written consent. Patients were included if they are clinically stable, without change of ART, with an estimated 
GFR (eGFR) $>60 \mathrm{ml} / \mathrm{min} / 1.73 \mathrm{~m}^{2}$ during the study period. The eGFR was determined using the CKD-EPI formula [1]. Patients with creatinine levels higher than $110 \mu \mathrm{mol} / \mathrm{l}$ for male or $90 \mu \mathrm{mol} / \mathrm{L}$ for women were excluded. Patients were divided in four groups according to their ART: group $\mathrm{T}+/ \mathrm{r}-$ : receiving tenofovir, no ritonavir; group $\mathrm{T}+/ \mathrm{r}+$ : receiving tenofovir and ritonavir; group $\mathrm{T}-/ \mathrm{r}-$ : receiving no tenofovir, no ritonavir; and group $\mathrm{T}-/ \mathrm{r}+$ : receiving ritonavir, no tenofovir. RCV was calculated using the formula $\mathrm{RCV}=2^{1 / 2} * \mathrm{Z} *\left(\mathrm{CVa}^{2}+\mathrm{CVi}^{2}\right)^{1 / 2}$, with a $\mathrm{Z}$ score $=1.96$ for $\mathrm{p}<0.05$ [2]. Analytical coefficient of variation (CVa) was determined in accordance with the CLSI EP15 protocol [5]. A total CV (CVt) was calculated for each patient using the results of his four serial measures (0-6-12-24 months). The CVi was obtained after removing the analytical variation with the formula $\mathrm{CVi}=$ $\left(\mathrm{CVt}^{2}-\mathrm{CVa}^{2}\right)^{1 / 2}[6]$. The index of individuality (II) was assessed through the ratio $\mathrm{CVi} / \mathrm{CVg}$, with $\mathrm{CVg}$ calculated as between-subjects variation.

\section{Results}

The study group consisted of 124 HIV-positive ART experienced, mean of age $50 \pm 10$ years, $72 \%$ were male, $14.3 \%$ had hepatitis $C$ co-infection (anti-HCV +); 7.1\% arterial hypertension and $4.0 \%$ diabetes. Median [min-max] CD4 was 526 [141-1228] cells/mm, 83\% had undetectable viral load, $23.8 \%$ had AIDS stage. For all patients median [min-max] of creatinine during the study period was 73 [42-110] $\mu \mathrm{mol} / \mathrm{l}$, while median [min-max] of eGFR was 100 [62-151] $\mathrm{ml} / \mathrm{min} / 1.73 \mathrm{~m}^{2}$. Levels of creatinine and eGFR according to the ART group are presented in Table 1. CVa for creatinine measurement using a pool of plasma at $60 \mu \mathrm{mol} / \mathrm{L}$ was determined as $2.8 \%$. Results for calculation of $\mathrm{RCV}, \mathrm{CVi}, \mathrm{CVg}$, and II are presented in Table 2, for all patients and for groups according to the ART. A significant difference was observed between RCV calculated in patients receiving the association tenofovir and ritonavir compared to each other group $(\mathrm{p}<0.05)$. By contrast there is no difference of creatinine RCV between groups receiving no ritonavir with or whitout tenofovir ( $21.9 \%$ vs $19.7 \%)$. All groups exhibited an II $<0.6$, although patients of the group $\mathrm{T}+/ \mathrm{r}+$ have a different profile than the three others, with higher value of the index of individuality.

\section{Discussion}

This study determined for the first time the long term RCV of creatinine in HIV-positive adults, according to their ART. This approach would be of particular interest in these patients who are monitored longitudinally in order to identify a critical change in creatinine results. Our data evidenced higher biological variations in patients receiving the association of tenofovir and ritonavir compared to the three other groups.

In this study, CVa was acceptable in regard to the value of Cvi, as optimal value is considered for $\mathrm{CVa}=0.25 \times \mathrm{Cvi}$ and desirable value for $\mathrm{Cva}<0.5 \times \mathrm{Cvi}[6]$. In all groups, $\mathrm{CVg}$ was higher than previous data reported in healthy volunteers [7] or active subjects [8] but closed to values observed in renal transplant patients [4]. For all groups, the index of individuality (II) was $<0.6$, highlighting that classical interval

Table 1

Creatinine and eGFR median [min-max] during the study period according to the ART groups

\begin{tabular}{clc}
\hline & \multicolumn{1}{c}{ Creatinine } & eGFR \\
\cline { 2 - 2 } & $(\mu \mathrm{mol} / \mathrm{L})$ & $\left(\mathrm{ml} / \mathrm{min} / 1.73 \mathrm{~m}^{2}\right)$ \\
\hline $\mathrm{T}+/ \mathrm{r}-(\mathrm{n}=24)$ & $73[48-105]$ & $100[62-128]$ \\
$\mathrm{T}+/ \mathrm{r}+(\mathrm{n}=24)$ & $77[50-110]$ & $99[66-118]$ \\
$\mathrm{T}-/ \mathrm{r}-(\mathrm{n}=38)$ & $72[42-103]$ & $99[62-151]$ \\
$\mathrm{T}-/ \mathrm{r}+(\mathrm{n}=38)$ & $74[43-110]$ & $102[65-147]$ \\
\hline
\end{tabular}

Table 2

Calculation of inter-individual CV (CVg) and mean [95\% confidence interval] for intraindividual CV (CVi), for index of individuality (II) and for reference change value (RCV) in HIV-positive adults according to the ART.

\begin{tabular}{|c|c|c|c|c|c|}
\hline & \multirow[b]{3}{*}{$\mathrm{n}$} & \multirow{3}{*}{$\begin{array}{l}\frac{\mathrm{CVg}}{} \\
(\%)\end{array}$} & \multirow{3}{*}{$\frac{\frac{\mathrm{CVi}}{\text { Mean (\%) }}}{[95 \% \mathrm{CI}]}$} & \multirow{3}{*}{$\frac{\frac{\text { II }}{\text { Mean (\%) }}}{[95 \% \mathrm{CI}]}$} & \multirow{3}{*}{$\frac{\frac{\mathrm{RCV}}{\text { Mean (\%) }}}{[95 \% \mathrm{CI}]}$} \\
\hline & & & & & \\
\hline & & & & & \\
\hline All patients & 124 & 19.2 & $\begin{array}{l}7.4 \\
{[6.7-8.1]}\end{array}$ & $\begin{array}{l}0.39 \\
{[0.36-0.42]}\end{array}$ & $\begin{array}{l}22.5 \\
{[20.8-24.2]}\end{array}$ \\
\hline $\mathrm{T}+/ \mathrm{r}-$ & 24 & 20.9 & $\begin{array}{l}7.2 \\
{[5.6-8.8]}\end{array}$ & $\begin{array}{l}0.34 \\
{[0.27-0.42]}\end{array}$ & $\begin{array}{l}21.9 \\
{[18.0-25.8]}\end{array}$ \\
\hline $\mathrm{T}+/ \mathrm{r}+$ & 24 & 16.8 & $\begin{array}{l}9.7^{* \circ} \$ \\
{[8.2-11.1]}\end{array}$ & $\begin{array}{l}0.58^{* * 0 \circ} \$ \\
{[0.49-0.66]}\end{array}$ & $\begin{array}{l}28.0^{* \circ} \$ \\
{[24.2-31.8]}\end{array}$ \\
\hline $\mathrm{T}-/ \mathrm{r}-$ & 38 & 16.5 & $\begin{array}{l}6.4 \\
{[5.4-7.4]}\end{array}$ & $\begin{array}{l}0.39 \\
{[0.33-0.45]}\end{array}$ & $\begin{array}{l}19.7 \\
{[17.1-22.2]}\end{array}$ \\
\hline $\mathrm{T}-/ \mathrm{r}+$ & 38 & 20.8 & $\begin{array}{l}7.4 \\
{[6.2-8.6]}\end{array}$ & $\begin{array}{l}0.36 \\
{[0.30-0.41]}\end{array}$ & $\begin{array}{l}22.2 \\
{[19.1-25.2]}\end{array}$ \\
\hline
\end{tabular}

${ }^{*} \mathrm{p}<0.05,{ }^{* *} \mathrm{p}<0.001$ compared to $\mathrm{T}+/ \mathrm{r}-$ (Student's T-test).

${ }^{\circ} \mathrm{p}<0.05,{ }^{\circ} \mathrm{p}<0.001$ compared to $\mathrm{T}-/ \mathrm{r}+$ (Student's T-test).

$\$ \mathrm{p}<0.001$ compared to $\mathrm{T}-/ \mathrm{r}-$ (Student's T-test).

reference is of limited utility for creatinine interpretation in HIVpositive patients. Indeed, in this context, some patients would have critical change in their serial creatinine measure although remaining in the interval reference value [6]. So, it appears suitable to substitute the reference interval by RCV for monitoring of creatinine levels and eGFR in HIV-positive patients.

Interestingly, patients receiving tenofovir in association with ritonavir exhibit significant higher RCV than the three other groups (Table 2). Indeed, RCV in this group was $28 \%$ compared to $21.9 \%$ for tenofovir without ritonavir ( $\mathrm{p}<0.001$, Student's T-test) and to $22.2 \%$ for ritonavir without tenofovir ( $p<0.05$, Student's T-Test). It could be hypothesized that the association of tenofovir and ritonavir leads to high variability of creatinine. In HIV-ART experienced patients, several factors could affect creatinine levels. Difficulty remains to identify the part of creatinine variations due to an alteration of muscular mass, of glomerular function or of tubular secretion. Indeed beyond glomerular filtration, a part of creatinine is uptaked through basolateral transporters of proximal tubular cells and thereafter extruded at the apical membrane. In vitro studies, identified the organic cation transporter (OCT)-2 as main basolateral transporter of creatinine in human kidney cells [9]. More recently, using transfected cells, OAT- 2 and OCT- 3 were also identified in addition to OCT-2 as basolateral transporters of creatinine [10]. So, competitors for OCT transporters, such as antibiotic (fluoroquinolone) [11] or antiretroviral drug (dolutegravir) [12], lead to decreased uptake of creatinine and consequently mild increase of plasma creatinine levels. At the apical membranes of tubular cells, extrusion of creatinine involves human multidrug and toxin extrusion (MATE)-1 and -2 [13,14]. Some inhibitors of MATE-1 including cimetidine or antiretroviral drugs such as ritonavir and cobicistat could also decrease tubular secretion of creatinine [10]. By contrast tenofovir had only a weak inhibitory effect on MATE-1 [15]. However, it could be hypothetized that a synergistic effect of ritonavir and tenofovir occurred for inhibition of MATE-1, according to the higher RCV observed in patients receiving the association of both drugs.

\section{Conclusions}

The present study underlined the need to use RCV instead of interval reference for creatinine in HIV-positive patients receiving ART due to the low value of the index of individuality. Because a significant difference in RCV was observed between groups, determination of RCV according to the ART is of particular interest. This study highlighted that RCV of creatinine during ART was around $20 \%$ but could be higher using the association of tenofovir and ritonavir. So, RCV of creatinine should be established for all line of treatments, especially for association of antiretroviral drugs interacting with tubular transporter of creatinine such as ritonavir and cobicistat. 


\section{Conflict of interest and source of funding for this work}

None for any authors.

\section{References}

[1] Levey AS, Stevens LA, Schmid CH, Zhang YL, Castro III AF, Feldman HI, et al. CKD-EPI (chronic kidney disease epidemiology collaboration). A new equation to estimate glomerular filtration rate. Ann Intern Med 2009;150:604-12.

[2] Fraser CG, Harris EK. Generation and application of data on biological variation in clinical chemistry. Crit Rev Clin Lab Sci 1989;27:409-37.

[3] Ricós C, Iglesias N, García-Lario JV, Simón M, Cava F, Hernández A, et al. Withinsubject biological variation in disease: collated data and clinical consequences. Ann Clin Biochem 2007;44:343-52.

[4] Ozturk OG, Paydas S, Balal M, Sahin G, Karacor ED, Ariyurek SY, et al. Biological variations of some analytes in renal posttransplant patients: a different way to assess routine parameters. J Clin Lab Anal 2013;27:438-43. http://dx.doi.org/10.1002/jcla. 21625.

[5] Chesher Douglas. Evaluating assay precision. Clin Biochem Rev 2008;29:S23-6.

[6] Harris EK. Statistical aspects of reference values in clinical Pathology. Rev Prog Clin Pathol 1981;8:45-66.

[7] Ricos C, Alvarez V, Cava F, Garcia-Lario JV, Hernandez A, Jimenez CV, et al. Current databases on biologic variation: pros, cons and progress. Scand J Clin Lab Invest 1999;59:491-500

[8] Nunes LA1, Brenzikofer R, de Macedo DV. Reference change values of blood analytes from physically active subjects. Eur J Appl Physiol 2010;110:191-8. http://dx.doi. org/10.1007/s00421-010-1493-8.
[9] Urakami Y, Kimura N, Okuda M, Inui K. Creatinine transport by basolateral organic cation transporter hOCT2 in the human kidney. Pharm Res 2004;21:976-81.

[10] Lepist EI, Zhang X, Hao J, Huang J, Kosaka A, Birkus G, et al. Contribution of the organic anion transporter OAT2 to the renal active tubular secretion of creatinine and mechanism for serum creatinine elevations caused by cobicistat. Kidney Int 2014 Mar 19. http://dx.doi.org/10.1038/ki.2014.66.

[11] Imamura Y, Murayama N, Okudaira N, Kurihara A, Okazaki O, Izumi T, et al. Prediction of fluoroquinolone-induced elevation in serum creatinine levels: a case of drugendogenous substance interaction involving the inhibition of renal secretion. Clin Pharmacol Ther 2011;89:81-8. http://dx.doi.org/10.1038/clpt.2010.232.

[12] Reese MJ, Savina PM, Generaux GT, Tracey H, Humphreys JE, Kanaoka E, et al. In vitro investigations into the roles of drug transporters and metabolizing enzymes in the disposition and drug interactions of dolutegravir, a HIV integrase inhibitor. Drug Metab Dispos 2013;41:353-61. http://dx.doi.org/10.1124/dmd.112.048918.

[13] Otsuka M, Matsumoto T, Morimoto R, Arioka S, Omote H, Moriyama Y. A human transporter protein that mediates the final excretion step for toxic organic cations. Proc Natl Acad Sci U S A 2005;102:17923-8.

[14] Masuda S, Terada T, Yonezawa A, Tanihara Y, Kishimoto K, Katsura T, et al. Identification and functional characterization of a new human kidney-specific $\mathrm{H}+$ /organic cation antiporter, kidney-specific multidrug and toxin extrusion 2. J Am Soc Nephrol 2006; 17:2127-35.

[15] Stray KM, Bam RA, Birkus G, Hao J, Lepist EI, Yant SR, et al. Evaluation of the effect of cobicistat on the in vitro renal transport and cytotoxicity potential of tenofovir. Antimicrob Agents Chemother 2013;57:4982-9. http://dx.doi.org/10.1128/AAC. 00712-13. 